Nova Southeastern University

Florida

NOVA SOUTHEASTERN

UNIVERSTYY

NSUWorks

Marine \& Environmental Sciences Faculty Articles Department of Marine and Environmental Sciences

2-1-1990

\title{
Biozonation of Deep-Water Lithoherms and Associated Hardgrounds in the Northeastern Straits of Florida
}

Charles G. Messing

Nova Southeastern University, messingc@nova.edu

A. Conrad Neumann

University of North Carolina - Chapel Hill

Judith C. Lang

University of Texas - Austin

Find out more information about Nova Southeastern University and the Halmos College of Natural Sciences and Oceanography.

Follow this and additional works at: https://nsuworks.nova.edu/occ_facarticles

Part of the Marine Biology Commons, and the Oceanography and Atmospheric Sciences and Meteorology Commons

\section{Recommended Citation}

Messing, Charles G., A. Conrad Neumann, and Judith C. Lang. "Biozonation of deep-water lithoherms and associated hardgrounds in the northeastern Straits of Florida." Palaios (1990): 15-33.

This Article is brought to you for free and open access by the Department of Marine and Environmental Sciences at NSUWorks. It has been accepted for inclusion in Marine \& Environmental Sciences Faculty Articles by an authorized administrator of NSUWorks. For more information, please contact nsuworks@nova.edu. 


\title{
Biozonation of Deep-Water Lithoherms and Associated Hardgrounds in the Northeastern Straits of Florida
}

\author{
CHARLES G. MESSING \\ Nova University Oceanographic Center, 8000 North Ocean Dr., Dania, FL 33004 \\ A. CONRAD NEUMANN \\ Department of Geology, University of North Carolina, Chapel Hill, NC 27514 \\ JUDITH C. LANG \\ Texas Memorial Museum, University of Texas, Austin, TX 78705
}

PALAIOS, 1990, V. 5, p. 15-33

Elongated carbonate mounds ("lithoherms") oriented parallel to prevailing northerly bottom currents at moderate depths (500-700 m) along the western margin of the Little Bahama Bank exhibit a consistent faunal zonation characterized by attached, suspension-feeding invertebrates. The four most abundant macroepibenthic groups (alcyonarians, crinoids, sponges and stylasterid hydrocorals) dominate all hard substrates examined except upcurrent ends and crests of lithoherms. We recognize three faunal zones on these mounds: a Coral Zone (Lophelia prolifera) restricted to the upcurrent end; a Zoanthid Zone (?Gerardia sp.) along upcurrent crests, and a Crinoid/Alcyonarian Zone along lithoherm flanks and downstream crests. Taxa characteristic of the latter also occur on surrounding, low-relief hardgrounds but are accompanied by additional taxa usually absent from mounds. Intervening unconsolidated sediment is largely barren. Biozonation appears chiefly dependent on current flow regime and secondarily on substrate. The observed zonation occurs over a much smaller areal scale than previously reported for deep-water (non-hydrothermal) hard bottoms. Abrupt, small-scale faunal zonation can no longer automatically be considered as evidence of a shallow-water environment in interpreting fossil assemblages.

\section{INTRODUCTION}

Faunal assemblages on hard bottoms in deep water $(>200$ m) are among the least studied of marine communities (hydrothermal vents excepted). Traditional dredge and trawl surveys indicate that such assemblages are usually dominated by attached, suspension-feeding invertebrates (e.g., Sokolova, 1959). Photographic surveys and manned submersible observations indicate that such assemblages are strongly dependent on current conditions and may not be space limited (Pratt, 1967; Genin et al., 1984, 1986; Grigg, 1974, 1984, 1988; Boehlert and Genin, 1987).

Neumann et al. (1977) described dense and diverse assemblages dominated by attached suspension-feeders on elongated carbonate mounds (lithoherms) up to $300 \mathrm{~m}$ long and $50 \mathrm{~m}$ high in $600-800 \mathrm{~m}$ in the northeastern Straits of Florida [although more recent observations (A.C.N., unpubl.; Mullins and Neumann, 1979) indicate the depth range is closer to $500-700 \mathrm{~m}$ ]. Initial observations suggested that wide variations exist in the fauna among different lithoherms. In this paper, we report the results of subsequent dives which reveal a consistent fauna distributed in distinctive zones apparently in response to variations in flow regime over mounds. The zonation appears on a much smaller areal scale than previously reported for deep-water (aphotic) hard-bottom assemblages not associated with hydrothermal vents (Stetson et al., 1962; Squires, 1963; Boehlert and Genin, 1987; Grigg et al., 1987). Zonation of hard substrate assemblages at aphotic depths

$0883-1351 / 90 / 0005-0015 / \$ 3.00$ 
TABLE 1-Study area submersible dive data. Numbers at left correspond to dive site numbers in Fig. 1.

\begin{tabular}{clccl}
\hline \hline & Dive number & Location & Max. depth & Observer \\
\hline Alvin & & & & \\
1. & 760 & $27^{\circ} 04 .^{\prime} \mathrm{N}, 79^{\circ} 19.9^{\prime} \mathrm{W}$ & $625 \mathrm{~m}$ & A.C.N. \\
2. & 761 & $27^{\circ} 04.4^{\prime} \mathrm{N}, 79^{\circ} 18.8^{\prime} \mathrm{W}$ & $611 \mathrm{~m}$ & J.C.L. \\
3. & 762 & $27^{\circ} 031^{\prime} \mathrm{N}, 79^{\circ} 19.3^{\prime} \mathrm{W}$ & $620 \mathrm{~m}$ & A.C.N., J.C.L. \\
4. & 1272 & $27^{\circ} 03^{\prime} \mathrm{N}, 79^{\circ} 23^{\prime} \mathrm{W}$ & $672 \mathrm{~m}$ & A.C.N., B. d'Argenio \\
5. & 1273 & $27^{\circ} 03^{\prime} \mathrm{N}, 79^{\circ} 23^{\prime} \mathrm{W}$ & $672 \mathrm{~m}$ & A.C.N., E.L. Sikes \\
6. & 1334 & $27^{\circ} 04^{\prime} \mathrm{N}, 79^{\circ} 20^{\prime} \mathrm{W}$ & $614 \mathrm{~m}$ & A.C.N., E.L. Sikes \\
7. & 1335 & $27^{\circ} 04^{\prime} \mathrm{N}, 79^{\circ} 20^{\prime} \mathrm{W}$ & $635 \mathrm{~m}$ & A.C.N., C.G.M. \\
8. & 1336 & $27^{\circ} 04^{\prime} \mathrm{N}, 79^{\circ} 20^{\prime} \mathrm{W}$ & $624 \mathrm{~m}$ & E. Druffel, C. Pilskaln \\
Sea-Link & & & $631 \mathrm{~m}$ & C.G.M. \\
9. & $9-\mathrm{XI}-87-2$ & $26^{\circ} 57.63^{\prime} \mathrm{N}, 79^{\circ} 17.04^{\prime} \mathrm{W}$ & &
\end{tabular}

provides additional evidence that similar fossil assemblages, previously considered to be shallow-water buildups, may actually have developed in deeper water (Teichert, 1958; Squires, 1964; Mullins et al., 1981; Cairns and Stanley, 1982; Stanley and Cairns, 1988).

\section{MATERIALS AND METHODS}

Lithoherms and intervening bottoms were examined during three series of DSRV Alvin dives west of Little Bahama Bank in the vicinity of Memory Rock, chiefly between 580 and $630 \mathrm{~m}$. The senior author made additional observations during a dive aboard the Johnson-Sea Link (Table 1, Fig. 1). Visual records were made via hand-held and externally mounted $35 \mathrm{~mm}$ cameras (the latter triggered by an intervalometer) and video; verbal commentaries were recorded on cassette tapes. Because the Alvin dives were primarily geological in investigative intent, complete suites of observed macrofauna were not collected and quantitative transects were not made. We have thus not yet quantified how the fauna varies either among lithoherms or relative to current flow and topography. We identified some taxa from collected material; other taxa, recorded photographically, have been identified from specimens collected in the same area and depth by University of Miami vessels (material housed in the Rosenstiel School of Marine and Atmospheric Science Invertebrate Museum). A number of taxa, chiefly sponges, remain unidentified and are referred to by one or more gross morphological attributes (e.g., stalked ball sponge). Specimens collected during these dives are housed in the National Museum of Natural History, Department of Invertebrate Zoology.

Absolute macrofaunal densities could not be calculated because rugged bottom contours prevented external cameras from photographing a uniform bottom area. The Alvin Users Manual (Bland et al., 1976), allowed us to calculate a maximum bottom area per frame and thus estimate macrofaunal densities in some cases. Densities were also estimated from the known size of the plastic crate attached to Alvin's collecting basket and visible in the external camera's field of view. Densities and frequencies of appearance of taxa in different local habitats are drawn from verbal commentaries, examination of hand-held camera photographs and 867 external $35 \mathrm{~mm}$ camera frames exposed during dives 1334, 1335, and 1336. Duplicate and overlapping views of the same specimens were not included (Tables 2,3).

\section{PHYSICAL SETTING}

The Straits of Florida form an arcuate trough that separates peninsular Florida from the Bahama Islands and Cuba, and connects the eastern Gulf of Mexico with the Atlantic Ocean. Dive sites are located along the eastern margin of the northern Straits which extends southward from about $27^{\circ} 25^{\prime} \mathrm{N}$ to Cay Sal Bank and belongs to an extensive, subsiding carbonate platform that includes the Florida Plateau and Bahama Banks (Fig. 1) (Malloy and Hurley, 1970).

Hydrographically, the Straits of Florida are dominated by the Florida current, a segment of the North Atlantic western boundary current continuous with the Gulf Stream. Current flow over the floor and slopes of the northeastern straits is northerly. Deep flow reversals described for the continental margin of the Straits (Düing and Johnson, 1972) are unknown along the insular margin. The northerly component of the Florida Current's mean velocity field in the study area is $10-20 \pm 12-14 \mathrm{~cm} / \mathrm{sec}$; velocity contours parallel the bottom and increase away from it (Leaman et al., 1987). Neumann et al. (1977) recorded (via timed dye release) velocities of $2-7 \mathrm{~cm} / \mathrm{sec}$ to the north over sediment-covered bottoms between mounds. We recorded current velocities exceeding $100 \mathrm{~cm} / \mathrm{sec}$ over upcurrent crests of large lithoherms (estimated from the submersible's ability to maintain position or drive against the current). Temperature in the study site area ranges from about $10^{\circ}$ to $12^{\circ} \mathrm{C}$ (Fig. 2) (Leaman et al., 1987).

Lithoherms are elongated, rocky, moundlike ridges up to $300 \mathrm{~m}$ long and $50 \mathrm{~m}$ high, oriented with their long axis 


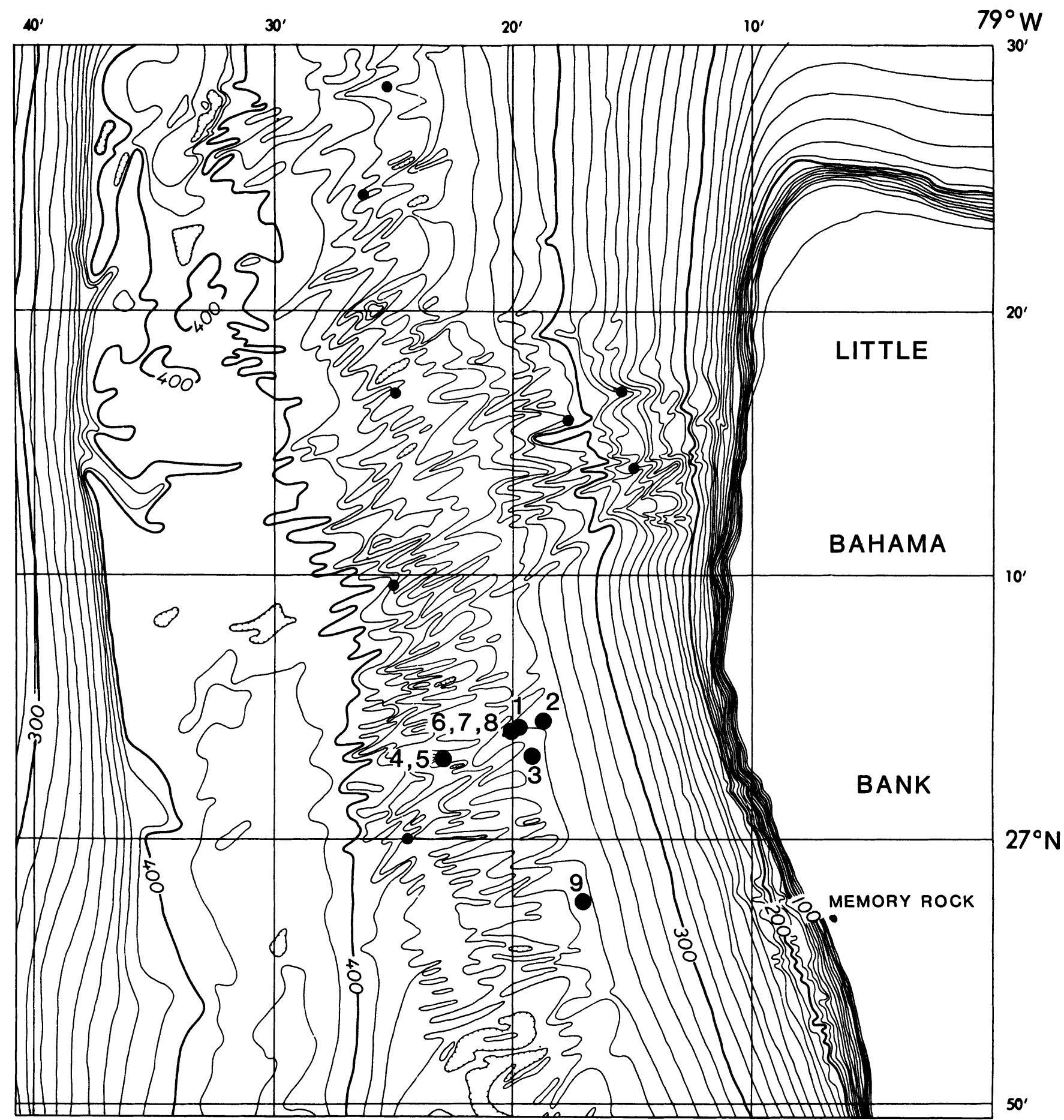

FIGURE 1-Bathymetric chart of study area. Large circles indicate submersible dive sites; numbers correspond to listing in Table 1. Small circles indicate rock dredge sites within lithoherm depth range (Wilber, 1976). Lithoherms chiefly occur here in a narrow band in 550-700 $\mathrm{m}$ parallel to the margin of Little Bahama Bank. The complicated bathymetry of east-west trending ridges and valleys does not accurately contour north-south oriented lithoherms. The central axis of the northward flowing Florida Current is off the left side of the chart at about $79^{\circ} 50^{\prime} \mathrm{W}$. Contours in fathoms. Modified from Malloy and Hurley (1970). 
TABLE 2_Frequency of appearance of taxa in different local habitats based on presence/absence analysis of 867 externally-mounted $35 \mathrm{~mm}$ camera frames taken during ALVIN dives 1334, 1335, 1336. Data from the three dives have been combined for each habitat. Habitat types are not entirely mutually exclusive (e.g., frames dominated by low hardground often include areas of open sediment.) Successive frames showing the same individuals have been recorded only once. + indicates presence in fewer than $1.0 \%$ of frames. Taxa not appearing in more than $1.0 \%$ of frames in any habitat are not included. Taxa are listed in descending order of abundance within each group.

\begin{tabular}{|c|c|c|c|c|}
\hline & Open sediment & $\begin{array}{c}\text { Low hardground/ } \\
\text { pavement }\end{array}$ & Ridge flank & $\begin{array}{l}\text { Steep flank/ } \\
\text { ridge crest }\end{array}$ \\
\hline Total frames & 306 & 190 & 260 & 111 \\
\hline \multicolumn{5}{|l|}{ Porifera } \\
\hline All species & $20.6 \%$ & $94.7 \%$ & $82.3 \%$ & $72.1 \%$ \\
\hline Knobs $(<\sim 3 \mathrm{~cm})$ & 1.0 & 63.7 & 42.3 & 38.7 \\
\hline Lumps $(>\sim 3 \mathrm{~cm})$ & 2.0 & 52.6 & 56.2 & 44.1 \\
\hline Phakellia sp. & 14.4 & 63.7 & 16.5 & - \\
\hline Pachastrellidae (band shell) & 2.3 & 42.6 & 17.3 & 4.5 \\
\hline Yellow lump & - & 10.5 & 13.1 & 3.6 \\
\hline Farrea sp. & + & 12.1 & 10.0 & 4.5 \\
\hline Stalked ball & + & 9.5 & 8.8 & 9.0 \\
\hline Pachastrellidae (white wall) & + & 5.3 & 12.3 & 14.4 \\
\hline ?Corallistes sp. & - & 1.1 & 10.4 & 26.1 \\
\hline Lithistida (shelf/dish) & - & - & 5.4 & 16.2 \\
\hline Small sphere & - & 6.3 & 4.2 & 1.8 \\
\hline Encrusting sponge & - & 1.1 & 8.8 & 6.3 \\
\hline ?Euplectella sp. & - & 2.6 & 7.3 & 6.3 \\
\hline Large amorphous & + & 4.7 & 2.7 & 1.8 \\
\hline Geodia sp. & + & 3.7 & 3.8 & 2.7 \\
\hline ?Caminus sp. & - & 3.2 & 2.7 & + \\
\hline Hyalonema sp. & + & 2.6 & 1.9 & + \\
\hline Large tube & - & - & 1.2 & 1.8 \\
\hline \multicolumn{5}{|l|}{ Cnidaria } \\
\hline \multicolumn{5}{|l|}{ Hydrozoa } \\
\hline Stylasteridae & 9.8 & 85.8 & 73.1 & 54.1 \\
\hline \multicolumn{5}{|l|}{ Alcyonaria } \\
\hline All Primnoidae ${ }^{a}$ & 65.7 & 97.9 & 91.9 & 72.1 \\
\hline Candidella imbricata & + & 58.4 & 33.5 & 12.6 \\
\hline Callogorgia sp. & 1.6 & - & - & - \\
\hline Corallium medea & 15.0 & 21.1 & 2.3 & - \\
\hline Paragorgia johnsoni & + & 3.6 & 3.8 & 2.7 \\
\hline Yellow plexaurid & + & 2.1 & 1.9 & - \\
\hline \multicolumn{5}{|l|}{ Scleractinia $^{b}$} \\
\hline Lophelia prolifera & - & - & 2.7 & 18.0 \\
\hline Solitary corals & - & - & 1.2 & 1.8 \\
\hline Actiniaria & - & - & 2.3 & 8.1 \\
\hline \multicolumn{5}{|l|}{ Zoanthidea } \\
\hline Gerardia sp. & - & - & 3.8 & 57.7 \\
\hline Antipatharia $^{c}$ & + & 1.6 & 1.2 & 2.7 \\
\hline Unidentified cnidarian stalks & 11.1 & 34.2 & 26.2 & 10.8 \\
\hline \multicolumn{5}{|l|}{ Polychaeta } \\
\hline Eunice sp. (with zoanthid) & 9.8 & 8.4 & 1.9 & + \\
\hline \multicolumn{5}{|l|}{ Crustacea } \\
\hline Galatheoidea & - & - & + & 13.5 \\
\hline
\end{tabular}


TABLE 2-Continued.

\begin{tabular}{|c|c|c|c|c|}
\hline \multicolumn{5}{|l|}{ Echinodermata } \\
\hline \multicolumn{5}{|l|}{ Crinoidea } \\
\hline All species & 42.2 & 93.2 & 81.2 & 70.2 \\
\hline ?Diplocrinus maclearanus & 22.9 & 75.3 & 66.9 & 55.0 \\
\hline Endoxocrinus parrae & 1.6 & 23.2 & 33.8 & 33.3 \\
\hline Isocrinus blakei & 17.0 & 35.8 & 7.3 & + \\
\hline Democrinus sp. & 8.5 & 24.7 & 16.2 & 8.1 \\
\hline Crinometra brevipinna & 3.9 & 17.9 & 16.2 & 13.5 \\
\hline Comatilia iridometriformis & - & - & 1.5 & 2.7 \\
\hline Unidentified comatulids ${ }^{d}$ & 4.9 & 5.3 & 10.0 & 16.2 \\
\hline \multicolumn{5}{|l|}{ Asteroidea } \\
\hline Unidentified species & 1.3 & 1.6 & 3.1 & 9.9 \\
\hline Goniasteridae & - & - & 2.3 & 10.8 \\
\hline Brisingidae & - & - & 2.3 & 4.5 \\
\hline \multicolumn{5}{|l|}{ Echinoidea } \\
\hline Unidentified species & 2.6 & 4.2 & 3.5 & 7.2 \\
\hline Paleopneustidae (tests) & 10.5 & 5.3 & + & - \\
\hline Ophiuroidea & 2.6 & 2.6 & 1.5 & 2.7 \\
\hline Fish ${ }^{\mathrm{e}}$ & 1.6 & 2.6 & 1.5 & 4.5 \\
\hline Thalassia testudinum (blades) & 14.7 & 8.9 & 4.6 & 3.6 \\
\hline Trails & 9.5 & 4.7 & - & - \\
\hline Rubble & $63.4^{\mathrm{f}}$ & $11.1^{\mathrm{f}}$ & $44.6^{\mathrm{g}}$ & $30.6^{\mathrm{g}}$ \\
\hline
\end{tabular}

aVirtually all Primnoidae not otherwise identified are Plumarella, probably $P$. pourtalesi.

${ }^{\mathrm{b}}$ Other potentially constructional corals known from this area (e.g., Enallopsammia profunda and Solenosmilia variabilis) were not identified on these dives.

${ }^{\mathrm{c}}$ Chiefly flagelliform Stichopathes luetkeni.

dChiefly unidentified but including a few Trichometra cubensis.

${ }^{\mathrm{e} C h i e f l y ~ a n ~ u n i d e n t i f i e d ~ m a c r o u r i d . ~}$

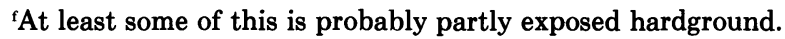

${ }^{8}$ Chiefly $L$. prolifera rubble.

parallel to the prevailing northerly bottom current (Figs. $3,4)$. They represent part of a wide swath of intermittent topographic irregularities that characterize the western slopes of the Bahama Platform from the Bimini Islands northward to the Blake Plateau. Neumann et al. (1977) described them as "deep, muddy [micritic] carbonate buildups formed by the constructive interaction of penecontemporaneous submarine lithification and organism attachment below the photic zone." Local topography variesmound crests range from broad and flat to keeled-but most give the impression of long, overturned boats in various stages of erosion. Flanks arise abruptly from the surrounding sediment although a narrow lithified apron is sometimes locally present. Slopes reach $60^{\circ}$ with locally vertical scarps. The upcurrent "bow" of mud and coral talus tends to be high, broad and round, although not always as steep as the flanks. The downcurrent "stern" usually becomes narrower and lower gradually, sometimes merging with one of the low rocky outcrops or crusts that cover extensive areas of sea floor between mounds, sometimes disappearing into a considerable sandy sediment shadow. The mound crest is highest near the upcurrent end and falls away gradually, but not always continuously, downcurrent.

Lithoherm rock is a dense, fossiliferous, thoroughly bored, muddy to sandy limestone. Structural material is a mixed pelagic foraminiferal/thecosome sand with a chiefly coarser admixture of locally derived calcareous skeletal remains (e.g., coral, mollusk, crinoid, echinoid and sponge) (Wilber, 1976; Neumann et al., 1977). Much of the lithoherm flank is a series of concentrically exposed, lithified crusts with relatively smooth hard upper surfaces and less consolidated, irregular lower surfaces. Material between successive crusts is poorly cemented or unconsolidated, resulting in characteristically bioeroded and undercut crescentic embayments along the flanks. When viewed from above, series of adjacent embayments often appear as narrow ridges parallel to the lithoherm's long axis. When viewed along the ridge flank parallel to the long axis, they are not as obvious and the lithoherm flank sometimes appears to fall into successive, irregular, downslope ridges and reentrants oriented as a ship's ribs. Flanks and crest along the downcurrent end may be relatively smooth though irregularly pitted and bored. Relief tends to increase up- 
TABLE 3-Maximum numbers (and densities when calculable) of taxa visible in individual externally-mounted 35 $\mathrm{mm}$ camera frames during dives 1334,1335 , and 1336 . Only those taxa recorded in numbers greater than one are included.

\begin{tabular}{|c|c|c|c|}
\hline Porifera & & Polychaeta & \\
\hline Knobs/lumps & $\left(\sim 12-15 / 0.1 \mathrm{~m}^{2}\right)$ & Eunice sp. (with zoanthid) & 22 \\
\hline Phakellia sp. & 10 & & \\
\hline Pachastrellidae (band shell) & 5 & Crustacea & \\
\hline Yellow lump & 2 & Galatheoidea & 2 \\
\hline Farrea sp. & 2 & & \\
\hline Stalked ball & 4 & Echinodermata & \\
\hline Pachastrellidae (white wall) & 3 & ?Diplocrinus maclearanus & $85+$ \\
\hline Lithistida (all species) & $40+$ & Endoxocrinus parrae & 8 \\
\hline Small sphere & 6 & Isocrinus blakei & 5 \\
\hline Encrusting sponge & 8 & Democrinus sp. & $20\left(12 / \mathrm{m}^{2}\right)$ \\
\hline ?Euplectella sp. & 3 & Crinometra brevipinna & 4 \\
\hline Hyalonema sp. & 2 & $\begin{array}{l}\text { Comatilia iridometriformis } \\
\text { Goniasteridae }\end{array}$ & $\begin{array}{c}100+ \\
3\end{array}$ \\
\hline Cnidaria & & Brisingidae & 7 \\
\hline Stylasteridae & $41+\left(24 / 2-3 \mathrm{~m}^{2}\right)$ & Paleopneustidae (tests) & 6 \\
\hline Plumarella spp. & $55+\left(\sim 20 / \mathrm{m}^{2}\right)$ & & \\
\hline Candidella imbricata & 40 & & \\
\hline Corallium medea & 4 & & \\
\hline Paragorgia johnsoni & 2 & & \\
\hline Lophelia prolifera & $\sim 7$ & & \\
\hline Solitary corals & 3 & & \\
\hline Actiniaria & 12 & & \\
\hline Gerardia sp. & 25 & & \\
\hline
\end{tabular}

ward, and higher reaches of the crest are in places deeply bioeroded, leaving strongly undercut crusts or isolated mesa-like and labyrinthine topography with a relief of $1-$ $2 \mathrm{~m}$. Lithoherm structure remains variable enough so that local areas of flank base vary among relatively smooth scarps, sloping series of embayments, and rubbly masses of broken crusts. Sediment occurs as a thin veneer with deeper pockets in embayments and hollows.

Larger lithoherms are rarely separated by less than a hundred meters and are often at least several hundred meters apart. Intervening bottom is largely pelagic foraminiferal/thecosome sand, chiefly rippled but smooth, lineated or weakly bioturbated in places, including a 3-4 m wide apron adjacent to steep lithoherm flanks. Sedimentveneered, lithified pavements having the same basic structure as lithoherm crusts, cover substantial between-mound area and are accompanied by scattered, small, irregular, outcropping ridges, crusts and mounds, some of which suggest themselves as incipient lithoherms or eroded remnants.

\section{BIOZONATION}

Macroepibenthic faunal assemblages on all hard substrates examined during this study are dominated by suspension-feeding invertebrates. The four most abundant groups: primnoid alcyonarians, crinoids, sponges and stylasterid hydrocorals, appear in 81.4, 68.6, 61.9 and $51.1 \%$, respectively, of the 867 external camera frames analyzed for dives 1334, 1335 and 1336 (Table 2). When the 306 frames showing chiefly unconsolidated sediment are not considered, these figures increase to $90.0,83.1,84.5$ and $73.6 \%$. A few other taxa are locally abundant in limited areas (e.g., zoanthids and hard corals on upcurrent crests) but none appear in any more than $8.5 \%$ of all frames. Several other macroinvertebrate groups characterized by the smaller sizes or cryptic behavior of many locally occurring species (e.g., ophiuroids, gastropods and decapod crustaceans) are likely present in significant numbers (based on qualitative examination of extensive trawled material ${ }^{1}$ ) but were infrequently distinguished by observational methods available to us.

Taxonomic composition of assemblages varies with substrate and flow regime. However, a few taxa, notably the primnoid alcyonarian genus Plumarella $[P$. pourtalesi (Verrill)] was collected but several morphologically similar species are known from the area] and the stalked crinoid ?Diplocrinus maclearanus (Carpenter), occur plentifully on almost all hard substrates examined (Figs. 5A, B, D, 7A, 8A).

We recognize three faunal zones on lithoherms (Figs. 3, 4) as follows:

\footnotetext{
${ }^{1}$ Between 1964 and 1972, the University of Miami's R/V Gerda occupied about 675 successful dredge and bottom trawl stations in the Straits of Florida. Cairns $(1979,1986)$ and Meyer et al. (1978) list station data for scleractinian corals, stylasterid hydrocorals and crinoids, respectively.
} 

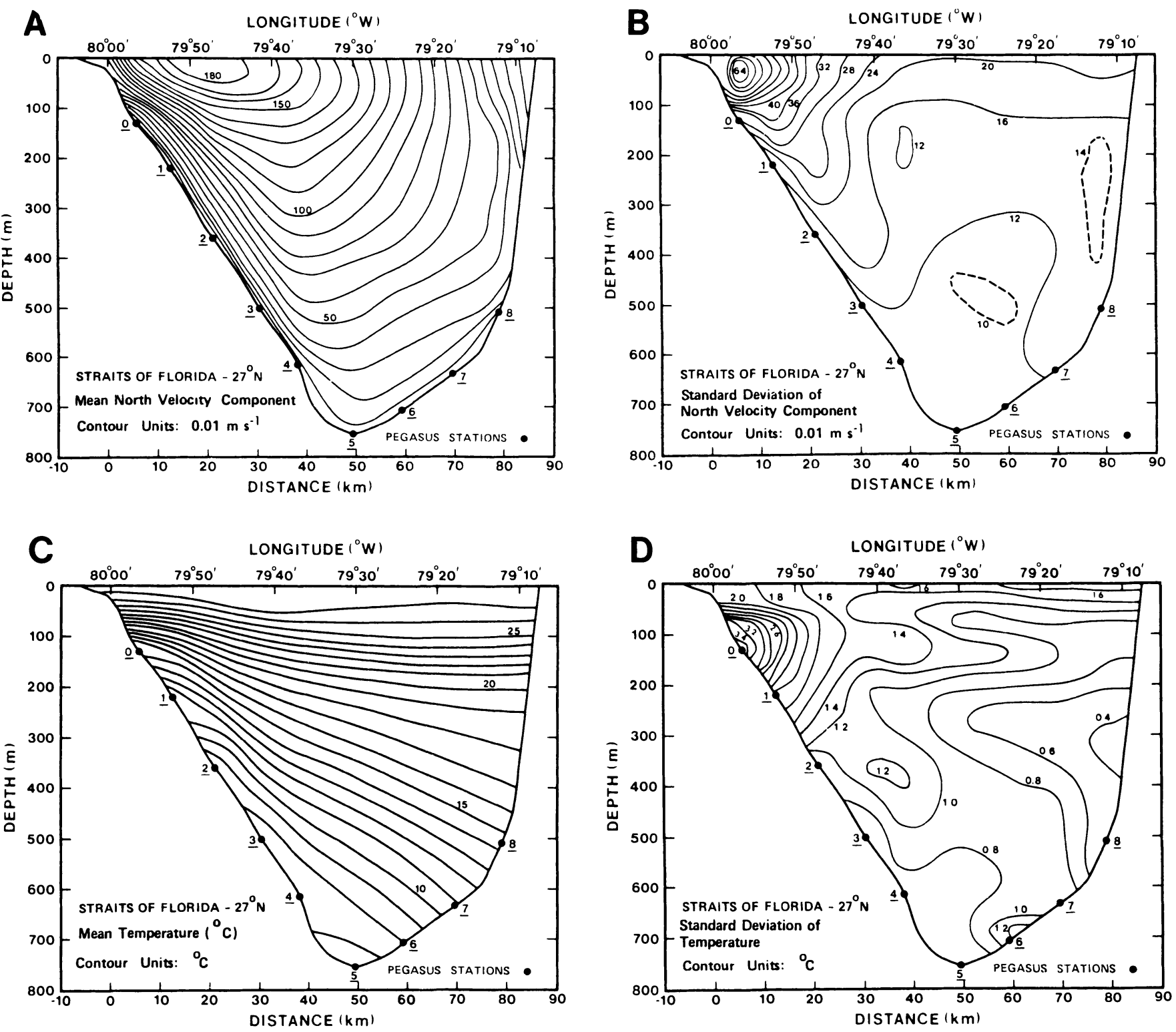

FIGURE 2-Cross section across the Straits of Florida at $27^{\circ} \mathrm{N}$ latitude showing A) mean northerly velocity component of the Florida Current, B) standard deviation of northerly velocity, C) mean temperature and D) standard deviation of temperature. Lithoherm dive sites located between Pegasus stations 7 and 8 (chiefly 550-620 m). (Reprinted with permission from Leaman et al., 1986.)

\section{Crinoid/Alcyonarian Zone}

Much of the lithoherms' surfaces are dominated by members of the four groups mentioned above. Alcyonarians and crinoids are the most obvious visual dominants on the flanks and along the downcurrent crests of lithoherms and we have termed these areas the Crinoid/Alcyonarian Zone (Figs. 4, 5A, B). The most abundant alcyonarian taxa here are members of the family Primnoidae that form monoplanar, pinnately (Plumarella) or dichotomously [Candidella imbricata (Johnson)] branched col- onies mostly less than $25 \mathrm{~cm}$ tall. The most abundant crinoids, ?Diplocrinus maclearanus and Endoxocrinus parrae (Gervais) (both Isocrinidae) attach to hard substrates via whorls of prehensile cirri that arise at intervals from their stalks; both species form parabolic filtration fans with arms deflected into the current and oral surfaces oriented downcurrent. The former is short-stalked, with a crown of usually less than 30 arms held adjacent to the substrate. The latter reaches $40 \mathrm{~cm}$ in height with a larger crown composed of up to 40 arms (Messing, 1985) (Fig. $5 \mathrm{~B})$. 


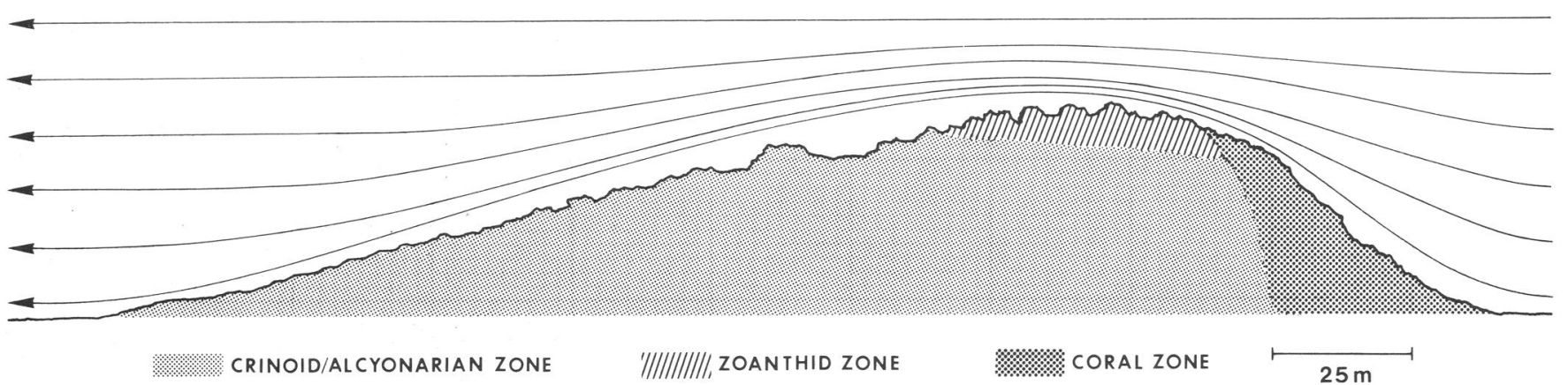

FIGURE 3-Schematic diagram of lithoherm biozonation showing conceptual compression of stream lines that produces rapid flow over crest. Maximum velocities recorded over crests (area of greatest compression) exceed $100 \mathrm{~cm} / \mathrm{sec}$; velocities recorded over sediment-covered areas between mounds are $2-7 \mathrm{~cm} / \mathrm{sec}$.

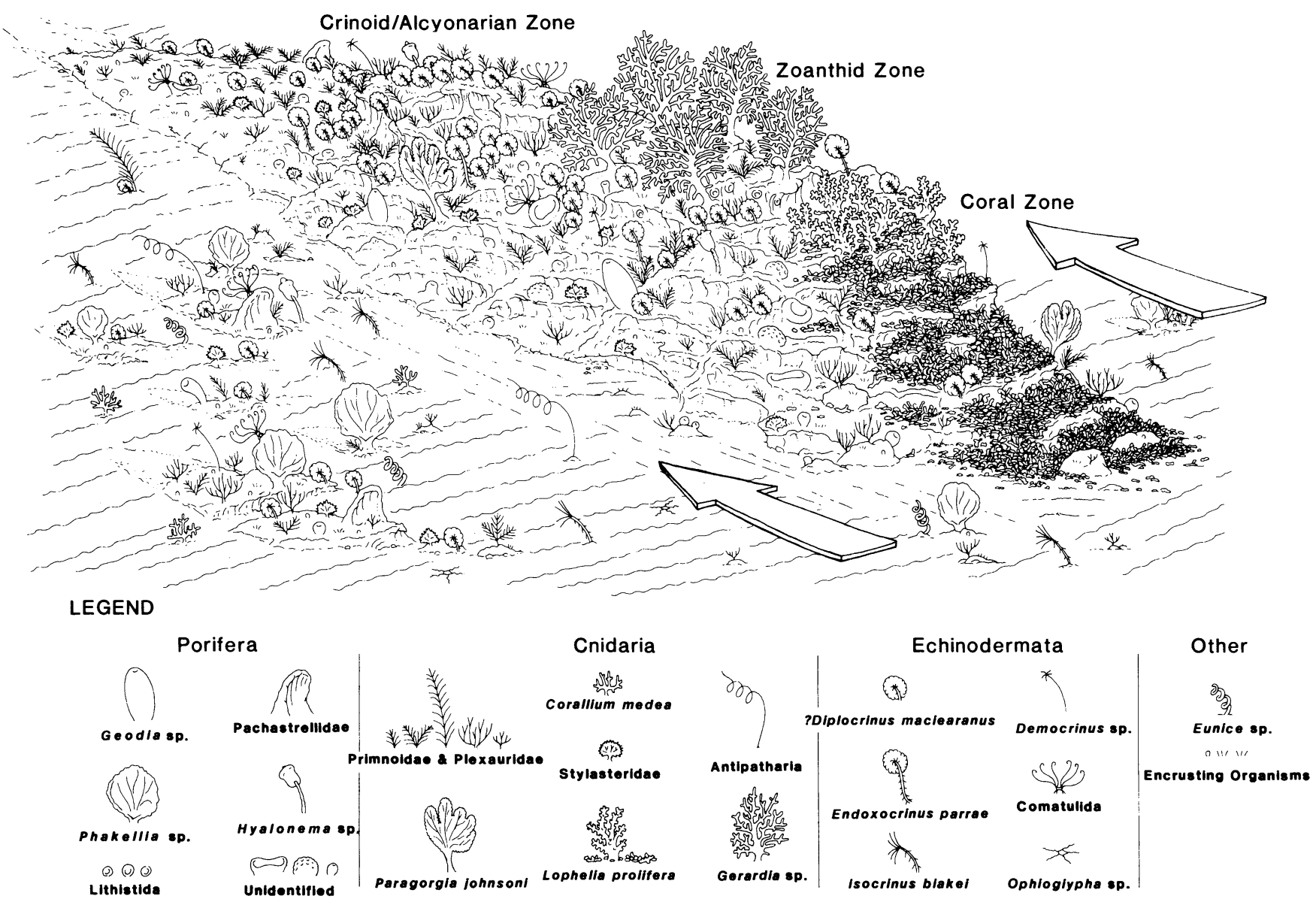

FIGURE 4-Schematic composite diagram of lithoherm biozonation (oblique view) showing distribution of major taxa. Taxonomic icons (identified in legend) are large in proportion to size of mound. The Crinoid/Alcyonarian Zone is truncated for simplicity. Inter-mound hardgrounds are shown at lower left. Arrows indicate current direction.

Sponges, including demosponges and hexactinellids, are the most diverse of major groups in the Crinoid/Alcyonarian Zone. We recorded over 20 distinguishable taxa ranging from forms visible only on collected rock samples, or as tiny shadow-casting knobs in photographs (Fig. 5A), to large barrels and amorphous masses up to a meter tall. The sponge fauna of this zone is richer than that of other zones and substrates examined but includes no character- 

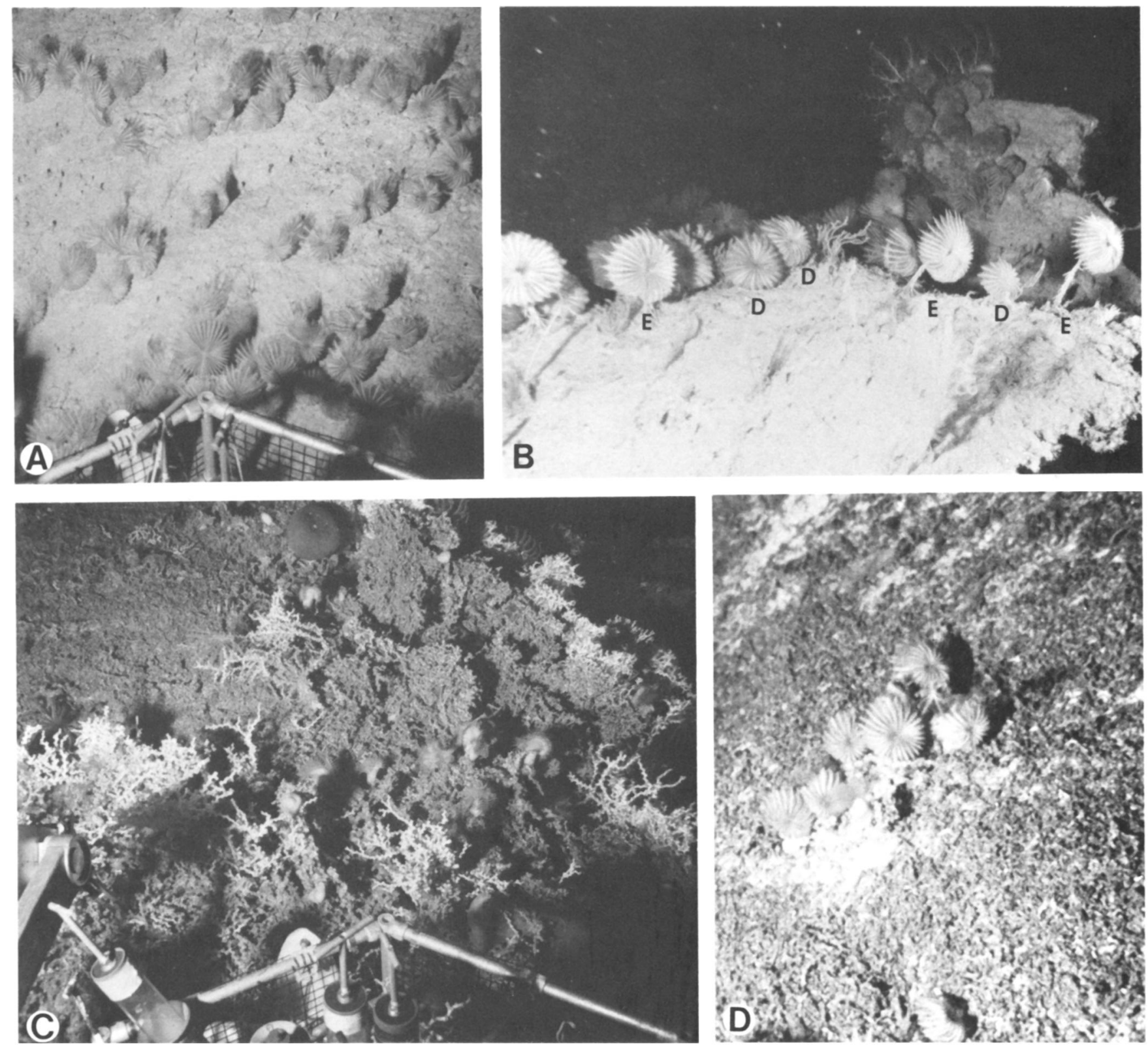

FIGURE 5-Lithoherm biozonation. A \& B. Crinoid/Alcyonarian Zone (depth: 550-600 m). A. Rows of stalked crinoids (chiefly ?Diplocrinus maclearanus) and small poriferan knobs. Alvin-761, photograph: J.C. Lang. B. High density of stalked crinoids on projecting margins of lithoherm crusts $(E=$ Endoxocrinus parrae; $D=$ ?D. maclearanus). Alvin-1335, photograph: C.G. Messing. (Current flow toward viewer.) C \& D. Coral Zone. C. Well-developed Coral Zone at upcurrent end of a lithoherm; numerous living colonies of the scleractinian coral Lophelia prolifera (white) veneer a massive rampart of dead coral infilled with sediment. Other visible organisms include sponge and actinians. Alvin-761, photograph: W.H.O.I. D. Discontinuous veneer of Lophelia prolifera rubble on the upcurrent slope of a lithoherm; with ?D. maclearanus. Alvin1334, photograph: W.H.O.I. (Diameter of ?D. maclearanus crowns approximately 10-12 cm.)

istic taxa. The most commonly occurring forms are more abundant on other bottoms [e.g., flabellate Phakellia sp. on surrounding low hardgrounds, and lithistids (e.g., Corallistes $\mathrm{sp}$. ) on vertical scarps near lithoherm crests] (Table 2).

Stylasterid hydrocorals, the fourth major macroinver- tebrate component, are neither morphologically nor taxonomically diverse. Although several species are known from the study area (Cairns, 1986), only two were collected during this study: Lepidopora glabra (Pourtalès) and Stylaster erubescens Pourtalès. Both form white, delicately branched, flabellate colonies not distinguished by us from 

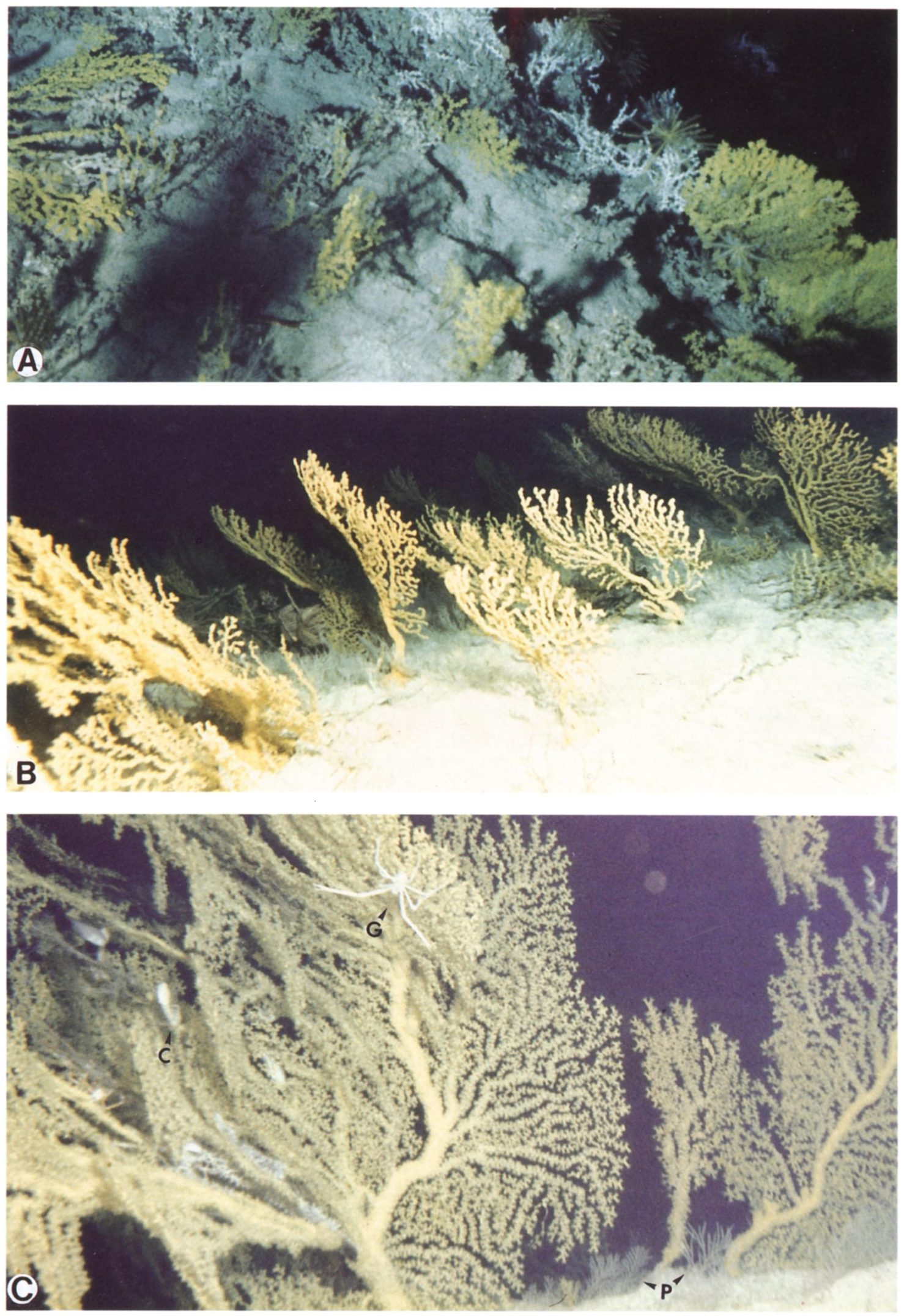
the submersible. They contrast strongly with the surrounding dark limestone substrate, however, and are among the most easily tallied organisms in photographs (Fig. 7A).

Crinoid/Alcyonarian Zone cover is typically short but dense; most primnoid colonies do not exceed $25 \mathrm{~cm}$ in height and stylasterine colonies and crinoid crowns are chiefly shorter. Organism density tends to increase up mound flanks. Isocrinids and alcyonarians occur at highest densities along projecting margins of crusts (Fig. 5B) and often appear planted in subparallel rows due to linearity of crust arrangement and/or in apparent avoidance of overlapping filtration surfaces (Fig. 5A). Monoplanar alcyonarians and stylasterids orient normal to current flow and often form lines down ridge flanks. The most abundant primnoid, probably Plumarella pourtalesi, reaches a fairly uniform maximum colony height here and often appears to form dense lawns when viewed at a low angle. ?Diplocrinus maclearanus reaches densities of 15-20 individuals/ $\mathrm{m}^{2}$ and alcyonarians almost certainly exceed this. However, Plumarella's slender branches and delicate colony form prevent resolution of many individual colonies in most photographs. Numerous small colonies on rock samples are not visible at all in photographs so that precise density estimates cannot be made. Similarly, small colonies of slender-branched plexaurid alcyonarians [e.g., Swiftia sp. (Stenogorgiinae)] identified from rock samples and in a few photographs and visual observations also likely occur in greater numbers than recorded by us.

\section{Zoanthid Zone}

A yellow, axis-secreting zoanthidean tentatively identified as Gerardia sp. ("gold coral") produces flabellate colonies up to about $1.0 \mathrm{~m}$ tall and $1.5 \mathrm{~m}$ across, oriented normal to current flow in often dense stands on lithoherm crests (Figs. 3, 4,6). This species occurs only at the highest elevations along the lithoherm axis and demarcates another distinct zone. This Zoanthid Zone is characterized by locally rugged, sometimes labyrinthine topography and steep scarps, and is subject to current velocities that may exceed $100 \mathrm{~cm} / \mathrm{sec}$. Such currents are strong enough to impede submersible operations and keep colony branches vibrating. Gerardia sp. was rarely observed more than a few meters below lithoherm crests and then chiefly as isolated colonies. It extends in numbers part of the way down the upcurrent flanks of only one mound examined, a particularly tall one (about $50 \mathrm{~m}$ ) bearing a massive coral rampart described below. Gerardia sp. is absent along much of the crests' downcurrent length where lower elevations are apparently shielded from high current velocities by greater upcurrent elevations. Low mounds may completely lack a Zoanthid Zone. We do not yet know the minimum mound height or associated current velocity required for development of this zone.

Typical Crinoid/Alcyonarian Zone taxa form a distinct understory in many areas within the Zoanthid Zone (Fig. $6 \mathrm{C})$. In some areas, however, the substrate is largely barren between Gerardia sp. colonies (Fig. 6A); short vertical to overhanging scarps associated with rugged topography at and near lithoherm crests exhibit a characteristic fauna of cup- and dishlike lithistid sponges (e.g., Corallistes sp.). These sponges appear to require hard substrates protected from sediment accumulation because they also appear along ridge flanks where occasional large crescentic embayments offer overhanging near-vertical surfaces similarly protected from sediment fall. Lithistids are typical of such microhabitats at similar depths $(+250 \mathrm{~m})$ elsewhere in the tropical western Atlantic [e.g., Jamaica (Lang, 1972), Cayman Islands (Messing, pers. obs.)]. Both flank embayments and rugged mound-crest relief appear largely due to bioerosional activity of clionid sponges which, though not abundant in photographs, are common in lithoherm rock samples.

\section{Coral Zone}

Gerardia sp. is replaced at the upcurrent end of lithoherms by the branching ahermatypic scleractinian coral Lophelia prolifera (Pallas). On most mounds examined, living coral is limited to relatively few scattered colonies at or near the upcurrent crest. However, Lophelia-derived rubble usually covers the entire upcurrent end of the lithoherms and may extend beyond the foot of the slope as a talus apron. We call this area of living and dead $L$. prolifera the Coral Zone (Figs. 3, 4, 5C, D). On some mounds, rubble forms a more or less continuous blanket from crest to base. On others, projecting margins of underlying lithified crusts like those along ridge flanks are visible through a rubble veneer. Many smaller mounds completely lack a Coral Zone and appear to be eroding remnants of lithoherms.

Lophelia prolifera was much more abundant on the upcurrent end of one lithoherm examined by two of us (A.C.N. and J.C.L., with T.P. Scoffin, University of Edinburgh). In this case, a veneer of living colonies covered a massive rampart of dead coral largely infilled with muddy sediment (Fig. 5C). Coral growth appeared to be prograding this

FIGURE 6-Lithoherm biozonation. Zoanthid Zone (depth: 550-580 m). A. Transition between Zoanthid Zone with numerous flabellate yellow Gerardia sp. (foreground) and Coral Zone with living and dead Lophelia prolifera (rear). Large comatulid crinoids (probably Crinometra brevipinna) cling to colonies of L. prolifera. Alvin-761, photograph: W.H.O.I. B. Numerous Gerardia sp. oriented normal to current flow from right. Alvin762, photograph: A.C. Neumann. C. Large Gerardia sp. with primnoid alcyonarian understory $(P)$. $(C=$ scalpellid cirripede, $G=$ chirostylid galatheoid anomuran). Alvin-761, photograph: J.C. Lang. (Foreground field of view: A, B-approx. 2.5 m; C-approx. 1.5 m.) 
rampart in an upcurrent direction. ${ }^{2}$ This structure is similar to deep-water coral banks found to the north of this study site on the Blake Plateau and northern margin of the Bahama Platform (Stetson et al., 1962; Mullins et al., 1981), and west Florida slope (Newton et al., 1987).

Taxa typical of the Crinoid/Alcyonarian Zone (as well as those of surrounding hardgrounds, e.g., P. pourtalesi, ?D. maclearanus, Democrinus sp.) also occasionally occur in the Coral Zone, especially where lithified crusts crop out along upcurrent flanks (Fig. 5D). However, the coral rubble provides a unique environment inhabited by taxa found in no other local habitat. It represents a complex microtopography protected from overlying high-velocity water movement and presumably suitable as shelter from predation for a variety of smaller taxa. Two of the most abundant forms restricted to this habitat include a pink unidentified actinian (Fig. 5C) and the tiny paedomorphic comatulid crinoid, Comatilia iridometriformis A. H. Clark. The latter reaches densities of 65 individuals $/ \mathrm{m}^{2}$; aspects of its life history and ecology, including habitat specificity, were discussed by Messing (1984). Other taxa include small asteroids, ophiuroids, crustaceans and the colonial pterobranch hemichordate Cephalodiscus atlanticus Bayer.

The demarcation between Zoanthid and Coral Zones along lithoherm crests may be clear-cut (Fig. 6A) or indistinct. Gerardia sp. colonies sometimes develop on hard substrates veneered with coral rubble, and we have observed $L$. prolifera colonies growing on dead portions of zoanthid colony axes.

\section{Inter-Mound Areas}

Hard substrates between lithoherms (Fig. 4) form a continuum ranging from low mounds indistinguishable from lithoherms except for their reduced size and extent (and lack of Coral or Zoanthid Zones, or both), through smaller outcropping crusts (Fig. 8B) and ridges, to flat, sedimentveneered pavements (Fig. 7A). These low-relief lithified carbonate surfaces appear to have the same basic structure as lithoherm-flank crusts though they are not as heavily bored nor have as many generations of infill and cement. All provide attachment sites for a variety of suspensionfeeding invertebrates. Concentrations of these organisms

\footnotetext{
${ }^{2}$ According to a model of lithoherm growth proposed by Neumann et al. (1977), submarine cementation by micritic (fine-grained) magnesian calcite is or was converting the sediment-infilled coral mass into a boundstone (coral/mud limestone). Rocks dredged or directly sampled from anywhere on the mounds contain coral, indicating that the bulk of the mound originates in the Lophelia-bearing upcurrent "nose."
}

act as a baffle to water flow, allowing suspended material to settle among them and sometimes to create extensive downcurrent sediment shadows (Fig. 8A). Periodic lithification of such deposits may be a means of increasing both the extent and elevation of local hardgrounds ${ }^{3}$, perhaps leading to lithoherm formation as epibenthos selectively attaches to raised areas. As with much of the lithoherm surface, these hardgrounds are veneered with sediment that pools in hollows and depressions. Isolated bits of rubble and shell are usually festooned with suspension-feeders and so function as hard substrates even when surrounded by extensive areas of unconsolidated sediment.

Species richness on inter-mound hardgrounds is similar to that typical of lithoherm flanks for all four major groups of suspension-feeders. Assemblages usually include most typical Crinoid/Alcyonarian Zone forms but also include important component taxa either absent from or infrequently present on large mounds. Taxa found on both lithoherms and low-relief hardgrounds include the sponges Farrea sp. and Euplectella sp., the alcyonarians Plumarella pourtalesi and Candidella imbricata, the crinoids ?Diplocrinus maclearanus, Democrinus sp., and Crinometra brevipinna (Pourtalès), and stylasterid hydrocorals. Taxa characteristic of low-relief hardgrounds alone include the fan sponge Phakellia sp., the alcyonarians $\mathrm{Co}^{-}$ rallium medea Bayer and Callogorgia sp., and the crinoid Isocrinus blakei (Carpenter) (Figs. 7, 8A). Endoxocrinus parrae is one of the few taxa found less frequently on lowrelief hardgrounds than on lithoherm flanks (see Table 2).

Phakellia sp. is particularly characteristic of low-relief crusts and flat pavements (Figs. 4, 7A, 8A). It is often accompanied here by dense populations of small knoband lumplike sponges that may exceed $100 / \mathrm{m}^{2}$ in places. These small sponges, which probably include immature specimens of species more easily distinguished when larger, also sometimes appear in equal abundance on more gently sloping lithoherm flanks. They are more easily recognized on flat pavements and crusts where they are less often obscured by dense stands of primnoid alcyonarians. Corallium medea and Isocrinus blakei also occur on such substrates (Fig. 7A). However, they appear in greatest relative abundances on chiefly unconsolidated sediment bottoms where they attach to low outcrops, small bits of rubble and shell, or empty spatangoid echinoid tests (e.g., Plethotaenia angularis Chesher) (Fig. 7B).

Unconsolidated sediment covers most of the sea floor observed during these dives. In addition to the 306 frames

\footnotetext{
${ }^{3}$ Slowey et al. (1989) has shown that periplatform oozes in Northwest Providence Channel, Bahamas (depth $655 \mathrm{~m}$ ), are more cemented during glacial than during interglacial epochs.
}

FIGURE 7-Inter-mound areas (depth: 600-620 m). A. Low-relief hardground; current toward viewer. Ph = Phakellia sp. fan sponge, Pa = pachastrellid sponge, $\mathrm{E}=$ Endoxocrinus parrae, $\mathrm{D}=$ ? Diplocrinus maclearanus, $\mathrm{Ca}=$ Candidella imbricata, St $=$ stylasterid hydrocorals, Co = Corallium medea. Alvin-760, photograph: W.H.O.I. B. Lineated sediment with suspension-feeding macroepibenthos attached to completely or partly buried hard substrates; current from right. $(\mathrm{C}=$ Callogorgia sp., $\mathrm{I}=$ Isocrinus blakei, $\mathrm{D}=\mathrm{Democrinus} \mathrm{sp}$., $\mathrm{T}=\mathrm{Thalassia}$. Other small visible organisms chiefly primnoid alcyonarians.) Alvin-1333, photograph: A.C. Neumann. (Foreground field of view: approx. 2.5 m.) 

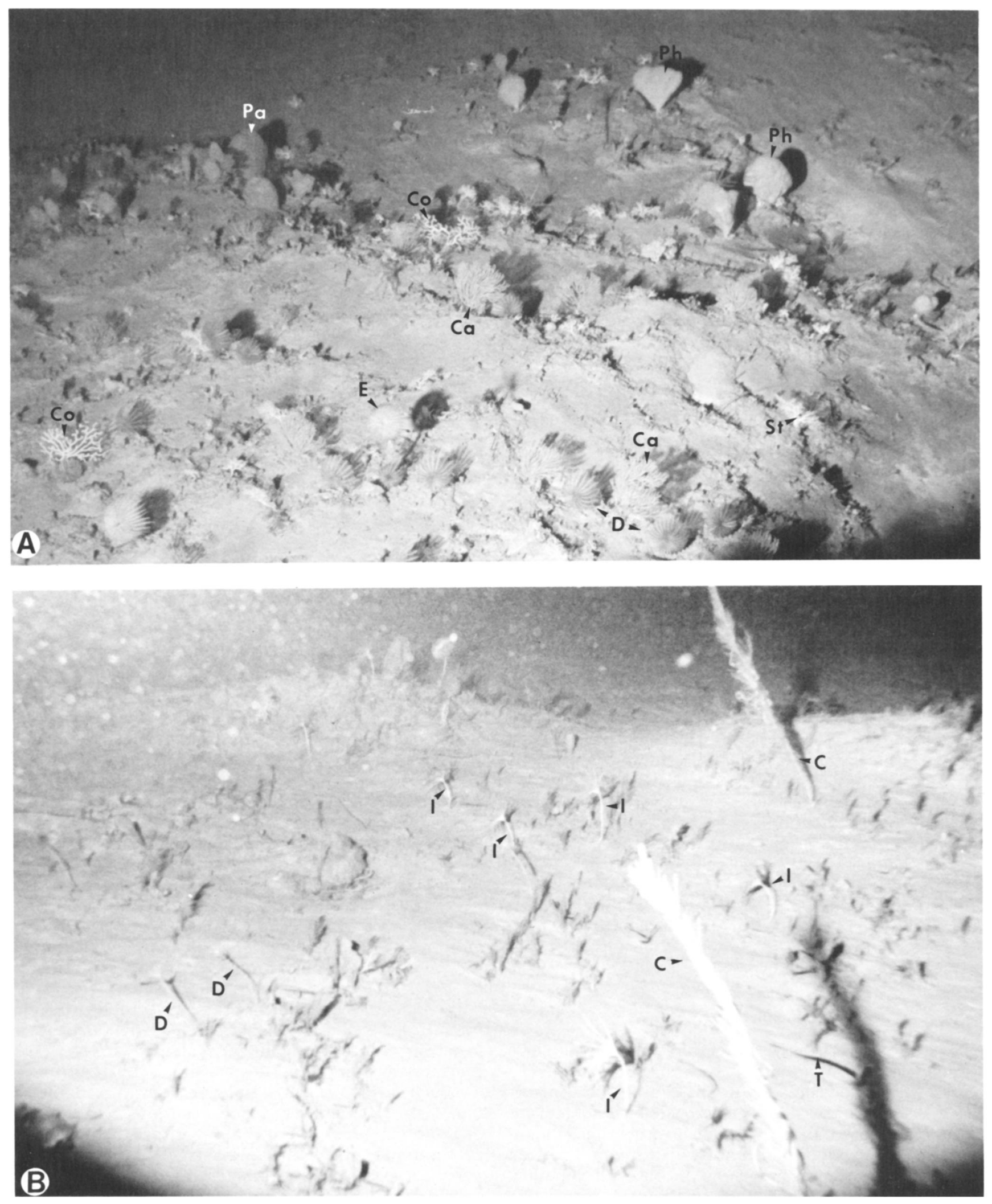

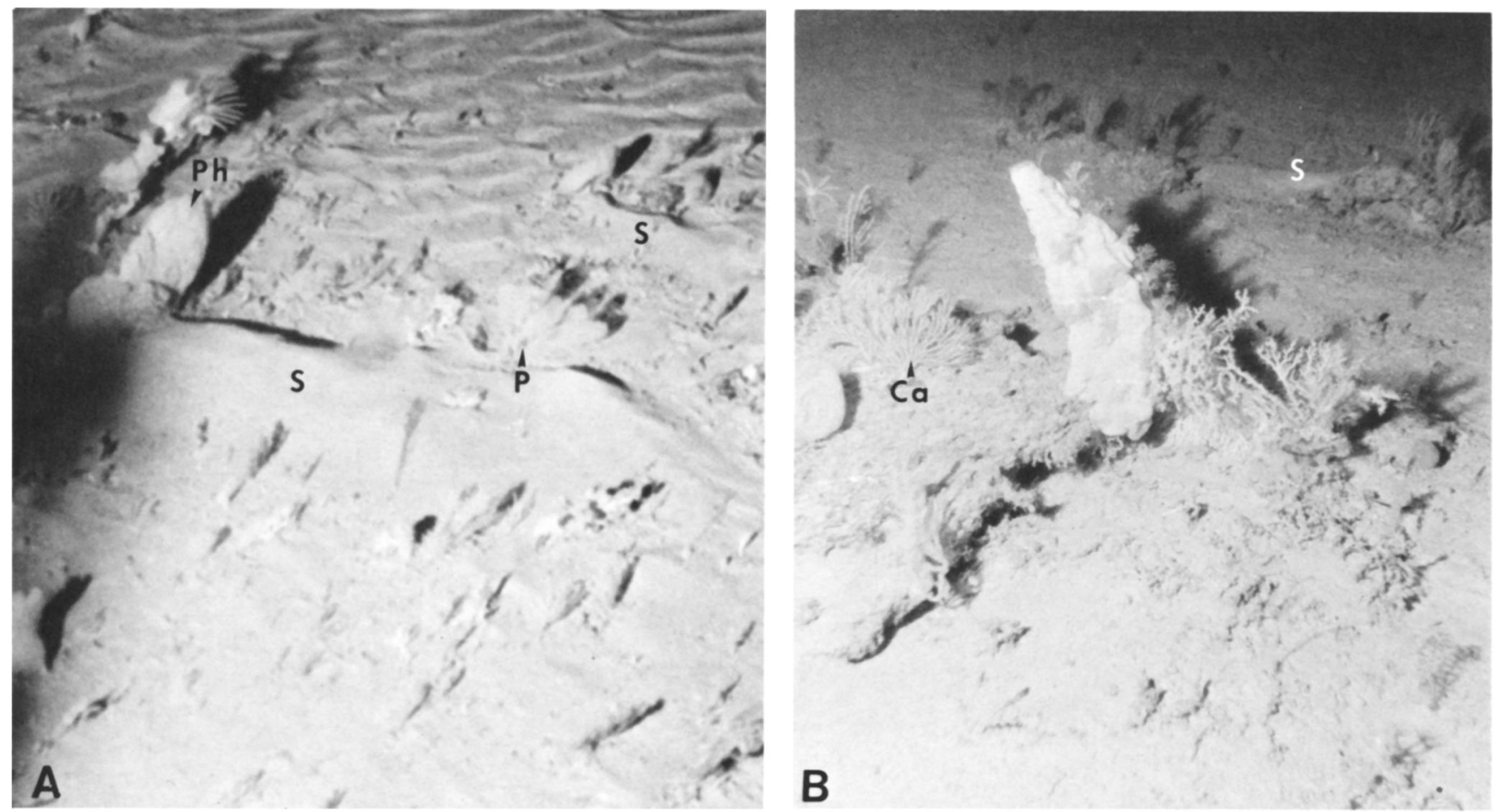

FIGURE 8-Inter-mound areas (depth: 600-620 m). A. Sediment shadows (S) (approx. 1.0-1.5 m long) formed downcurrent of sponges on low-relief hardground surrounded by inactive rippled sediment. Visible organisms chiefly primnoid alcyonarians and sponges. (Ph $=P$ Phakellia sp., $\mathrm{P}=$ Plumarella cf. pourtalesi) Alvin-760, photograph: W.H.O.I. B. Lithified crust-possibly an incipient lithoherm-crowded with sponges and cnidarians. Sponge height approx. 0.3-0.5 m. (S = sediment shadow, $\mathrm{Ca}=$ Candidella imbricata.) Alvin-364, photograph: A.C. Neumann.

showing such substrates in Table 2 (35\% of the total), many frames listed as "low hardground" also include substantial areas of sediment. Whether rippled, lineated or smooth, these sediments are almost completely barren, especially when compared with local hardgrounds. Organic content is low and extensive areas exhibit little or no visible bioturbation. Detrital blades of shallow-water sea grass, Thalassia testudinum Koenig \& Sims, are occasionally observed. Virtually all of the taxa listed in Table 2 as occurring on open sediment actually attach to completely or partly buried outcrops or bits of rubble and shell (Fig. 7B). The ophiuroid Ophioglypha sp. was the most frequently observed vagile benthic organism although decapod crustaceans (e.g., hermit crabs and shrimps) were occasionally seen.

\section{DISCUSSION}

The study area is a bathyal environment exposed to lowlatitude oceanic conditions. As such, most physical variables usually responsible for localized differential distribution, or zonation, of marine macroepibenthic organisms (e.g., temperature, salinity, periodic exposure and illumination) do not exhibit significant gradients here. They can be eliminated as factors governing the observed zonation.

Almost all macroepibenthic taxa observed during this study require hard substrates for permanent or temporary anchorage. Because hard substrates remain the same or similar in all habitats examined, that is, a largely sedimentveneered, carbonate rock, the primary cause of the observed differential distribution must be sought elsewhere. The only environmental factor that exhibits a recognizable gradient in repeated concord with organism zonation on hard substrates is current velocity. This factor ranges from less than $2 \mathrm{~cm} / \mathrm{sec}$ over areas of unconsolidated sediment (featureless, lineated, bioturbated or characterized by inactive ripple marks), to more than $100 \mathrm{~cm} / \mathrm{sec}$ over lithoherm crests. Most lithoherm crests examined range between 550 and $580 \mathrm{~m}$ below the sea surface. The northerly component of the Florida Current's mean velocity field here is $10-20 \pm 12-14 \mathrm{~cm} / \mathrm{sec}$; velocity contours parallel the bottom and increase away from it (Fig. 2) (Leaman et al., 1987). Mound crests that reach $50 \mathrm{~m}$ above surrounding bottoms represent significant local topographic irregularities. However, mean northerly velocities of $100 \mathrm{~cm} / \mathrm{sec}$ penetrate at most to about $350 \mathrm{~m}$ and only in the western central straits (Fig. 2A). (Leaman et al., 1987). As a result, although current velocities do increase away from the bottom, high velocities over mound crests are probably chiefly due to compression of stream lines rather than downward penetration of the main current axis (Fig. 3).

Water flow is a critical factor governing or modifying distribution, growth and form of suspension-feeding invertebrates (e.g., Riedl, 1971; Kinzie, 1973; Meyer, 1973; 
Boero, 1984; Sebens, 1984). Suspension-feeders dominate hardgrounds in the study area, and it seems clear that their local zonation is due largely to differing flow requirements or tolerances. The Coral Zone, dominated by Lophelia prolifera, appears only on larger lithoherms. The Zoanthid Zone remains on the crests of somewhat smaller mounds that lack a Coral Zone. The Crinoid/Alcyonarian Zone appears on the flanks and downcurrent crests of large lithoherms and covers proportionately more of the smaller mounds in which Coral and Zoanthid Zones are reduced or lacking. Our observations indicate that the current velocity gradient is responsible for the observed zonation and that greater velocities over mound crests and upper flanks are responsible for increased organism densities in those areas. Attached suspension-feeding invertebrates exhibit similarly increased densities in response to topographically intensified current flow over seamount peaks at similar bathyal depths (Genin et al., 1986; Boehlert and Genin, 1987; Grigg et al., 1987).

We do not yet know the limits of flow and topography required for development of these zones or the different assemblages characteristic of low hardgrounds between lithoherms. Similarly, it remains unknown at what life history stage flow requirements become important to the various taxa here. Flow may affect larval distribution and settlement or postlarval survival, or both. Local assemblages include both broadly and narrowly distributed taxa; the former (e.g., L. prolifera occurs from Norway to Brazil; Cairns, 1979) are unlikely to exhibit zonation based on limited larval dispersal whereas the latter may (e.g., the brooding comatulid Comatilia iridometriformis occurs only in the northern Straits of Florida and adjacent waters; Messing, 1984). Transplant experiments are necessary to determine if adult taxa characteristic of specific zones can survive in areas subject to different flow regimes.

Substrate variations do contribute to zonation to a limited extent. Lithistid sponges appear to be restricted to vertical and overhanging surfaces protected from sediment accumulation. Several taxa, notably an actinian and $\mathrm{Co}$ matilia iridometriformis, are apparently restricted to the uncemented Lophelia rubble microhabitat (Fig. 5C; Messing, 1984, fig. 2). Such variations among hard substrates differ from broader distinctions between assemblages on hard versus unconsolidated substrates (e.g., Hecker et al., 1980).

With the exception of hydrothermal vents, lithoherms exhibit faunal zonation on a smaller areal scale than other deep-water, hard-bottom assemblages. Transitions from Crinoid/Alcyonarian to Zoanthid Zone or Zoanthid to Coral Zone are on the order of one to a few meters (Fig. 5A). Zonation transitions recorded for seamount peaks (Genin et al., 1986; Boehlert and Genin, 1987; Grigg et al., 1987), submarine canyons (Hecker et al., 1980) and deep-water ahermatypic coral banks (Stetson et al., 1962; Squires, 1963) appear to occur on a scale of tens to hundreds of meters. Zonation on the order of one to a few meters has almost uniformly been associated with shallow-water assemblages subject to steep local gradients in a wide range of physicochemical parameters, e.g., temperature, salinity, illumination, aerial exposure, water movement and substrate composition. Such abrupt zonation in a deep-water environment exposed to oceanic conditions means that similarly zoned fossil assemblages can no longer automatically be considered as having developed in shallow water. Of course, unequivocal criteria for recognizing ancient shallow-water assemblages (e.g., traces of photosynthetic organisms) override any zonational observations. Lithoherms include components of deep-water coral bank assemblages; criteria for recognizing similar ancient assemblages as having developed in deep water have been discussed by Teichert (1958), Squires (1964), Cairns and Stanley (1982), Mullins et al. (1981) and Stanley and Cairns (1988).

Two of the most abundant taxa, the primnoid alcyonarian Plumarella pourtalesi and the isocrinid ?Diplocrinus maclearanus, exhibit no zonation and appear in large numbers on most hard substrates (Figs. 4, 5A, B, D, $7 \mathrm{~A}, 8 \mathrm{~A}$ ). However, both are short (usually no more than $15 \mathrm{~cm}$ high) and apparently do not extend beyond a lowvelocity boundary layer. Velocities probably remain relatively low in their height range despite increased flow at higher levels above the bottom (e.g., 0.5-1.0 m) that affects the distribution of taller taxa (although boundary layer velocities do depend on and correlate with free flow above the substrate).

Although we have stressed variations in current velocity and substrate as factors governing biozonation, it is important to recognize that these two factors, together with sufficient food particle flux, are largely responsible for the existence of the fauna itself as a dense and diverse assemblage of suspension-feeding organisms.

Photographic surveys and submersible observations indicate that deep-water $(>200 \mathrm{~m})$ assemblages on hard substrates in general do not appear to be space-limited (e.g., Heezen and Hollister, 1971; Lang, 1972; Grigg et al., 1987; Grigg, 1988; Messing, unpubl. obs.) [although exceptions do exist, e.g., Hecker et al. (1980); Boehlert and Genin (1987)]. High densities of suspension-feeders in the study area reflect the Florida Current's strong mean velocity field as well as topographically intensified flow. Elsewhere in the tropical western Atlantic at similar depths, hardground assemblages subject to reduced and perhaps oscillating (tidal) current flow exhibit much lower densities (Northwest Providence Channel, Exuma Sound, Turks and Caicos Islands; Messing and Neumann, unpubl. obs.). Increased flow may enhance densities of suspension-feeders by increasing larval recruitment rate (the settlement pathway of Genin et al., 1986) or rates of feeding and, consequently, growth rates (the feeding pathway) (see also Boehlert and Genin, 1987).

Composition and sources of food supporting the lithoherm fauna remain to be investigated. The diversity of suspension-feeders reflects a wide range of diets. Sponges, for example, largely capture particles $5 \mu \mathrm{m}$ or smaller whereas crinoids feed chiefly on particles in the 50-400 $\mu \mathrm{m}$ range. Their food may include living bathyal plankton or particulate detritus transported from shallow-water, or both. Griffin and Druffel (1989) have determined sources 
of skeletal carbon for four suspension-feeding taxa at the study site. Species that accrete organic skeletons (Gerardia sp., Paragorgia johnsoni) obtain carbon chiefly from surface-derived sources. Calcareous species (Lophelia, Corallium) extract dissolved inorganic carbon from the water at the depth at which they grow.

The age and stability of the lithoherm fauna likewise remain unknown. We lack any information on relative rates of lithoherm accretion (via skeletal accumulation, sediment deposition and cementation) versus erosion (via bioerosion especially by clionid sponges, and winnowing) except to say that some mounds appear to be actively accreting while others seem to be eroding remnants. We do know that community metabolic rates are characteristically lower in the deep sea than in shallow water, reflecting decreases in temperature and productivity (e.g., Smith and Hinga, 1983). Although increased food availability associated with the strong flow regime in the study area may drive higher community metabolic rates relative to areas subject to weaker currents, several factors suggest that such rates remain relatively low (at least relative to similar assemblages in shallower water): temperature is about $10-12^{\circ} \mathrm{C}$; organic content of available particulate material is apparently low, ${ }^{4}$ and almost all major taxa are highly skeletonized; that is, metabolically expensive tissues represent a very small percentage of biomass. The rarity of juvenile isocrinids suggests that the rate of recruitment of offspring to local populations is also low. Daily submersible observations of a local population of the isocrinid Cenocrinus asterius (Linnaeus) in $250 \mathrm{~m}$ off Georgetown, Grand Cayman Island have revealed no recruitment of juveniles over a period of three years (C. Platt, pers. comm.). If competition for space occurs on lithoherms and associated bottoms, it probably does so at a much slower pace than in shallower waters.

Radiocarbon measurements made on Gerardia sp. from the study area (Griffin and Druffel, 1989) exhibit a highly significant linear decrease in $\Delta^{14} \mathrm{C}$ values from the outside of the colony trunk inwards and suggest that the specimen may be over 1000 years old. Although the authors discuss and eliminate several sources of error, such a vast age must be treated as tentative pending further measurements. Even if this age value is significantly inflated, it is still possible that skeleton-accreting cnidarians may be old enough to obtain time histories of transient (e.g., bomb ${ }^{14} \mathrm{C},{ }^{90} \mathrm{Sr}$ ) and conservative (e.g., ${ }^{18} \mathrm{O} /{ }^{16} \mathrm{O},{ }^{13} \mathrm{C} /{ }^{12} \mathrm{C}$ ) tracers in the deep sea (Griffin and Druffel, 1989). Whether Gerardia sp. represents a "bathyal bristlecone pine" remains to be seen, however.

Hard substrates are widespread at aphotic depths throughout the world's oceans, e.g., on carbonate bank margins and continental slopes, plateaus, canyon walls and mid-ocean ridges, yet they remain among the least studied and understood of marine environments. Apart from logistics, analyses of the structure and dynamics of assem-

${ }^{4}$ A sediment trap experiment at $500 \mathrm{~m}$ depth in the Northwest Providence Channel (100 km from our study area) gave a vertical particulate mass flux of $59 \mathrm{mg} / \mathrm{m}^{2} /$ day of which organic material represented only 7\% (Pilskaln et al., 1989). blages associated with such environments are hampered by generally small, scattered populations, low recruitment and low metabolic rates associated with typically bathyal and abyssal conditions. Lithoherms and adjacent bottoms, with their dense populations and likelihood of relatively higher recruitment, feeding, and growth rates associated with the strong flow regime, represent an opportunity to analyze deep-water hard-bottom assemblages on a scale far more concentrated than that offered by the majority of such assemblages. The dense aggregations of heavily skeletonized taxa offer an opportunity to better understand and reconstruct fossil assemblages. For example, Wilson (1975) has suggested a similarity between lithoherms and late Paleozoic, Waulsortian-type mudmounds although Lees and Miller (1985) favor a shallow origin for the latter. But, because these mudmounds lack traces of photosynthetic organisms and are dominated by what appears to be submarine-cemented, sandy-to-muddy crinoidal limestones, they may yet be interpreted as deep-water, low-energy, low-oxygen analogs of lithoherms. A comparative study of lithoherms and Waulsortian-type deep reef mounds is underway but has been hampered by our current technical inability to systematically sample lithoherm interiors.

A great deal of information remains to be learned about lithoherms and deep-water hardground assemblages in general. The foregoing observations have been largely qualitative. Future investigations will pursue quantitative documentation of faunal variability among lithoherms; the relationships among zonation, topography and flow regime, and how these reflect organism life history strategies; community dynamics including analyses of food resources, larval recruitment and possible space competition, and a clearer understanding of lithoherm interior structure and development. Also, analysis of possible niche partitioning among stalked crinoids of differing heights and filtration characteristics may shed light on similar partitioning proposed for crinoids as far back as the Paleozoic (Ausich, 1981).

\section{ACKNOWLEDGMENTS}

We are most grateful to the following people and organizations for their assistance and support during the course of this investigation: Terence P. Scoffin, University of Edinburgh), Bruno d'Argenio (University of Naples, Italy), Shirley Pomponi (Harbor Branch Oceanographic Institution), the officers and crew of the research vessels Lulu, Atlantis II and Seward Johnson, the support personnel and crews of the research submersibles DSRV Alvin and Johnson-Sea-Link I, especially pilots Ralph Hollis and Dudley Foster (Alvin) and Tim Askew (JSL I). A. Genin read and critically commented on a late draft edition of the manuscript. Researchers who courteously gave of their time to identify specimens include Klaus Ruetzler, Stephen D. Cairns, Frederick M. Bayer, Kristian Fauchald, David L. Pawson, Maureen Downey (all National Museum of Natural History) and C. Richard Robins (University of Miami). Portions of this work were carried out as a result of support provided by National Science Foundation grant 
\#OCE-8315203 and National Cancer Institute contract \#NO1-CM-67919. This is Contribution No. 2 from the Deep Ocean Society and Publication No. NS-00 of the Texas Memorial Museum.

\section{REFERENCES}

Ausich, W. I., 1980, A model for niche differentiation in Lower Mississippian crinoid communities: Journal of Paleontology, v. 54, p. 273-288.

Bland, E.L., DonNelly, J.D., AND SHumakeR, L.A., 1976, Alvin user's manual, Woods Hole Oceanographic Institute Technical Manual 3-76: Woods Hole, Massachusetts.

Boehlert, G. W., AND Genin, A., 1987, A review of the effects of seamounts on biological processes, in Keating, B.H., FrYer, P., Batiza, R., and Boehlert, G.W., eds., Seamounts, islands and atolls, Geophysical Monographs (43): American Geophysical Union, Washington, D.C., p. 319-334.

BoERo, F., 1984, The ecology of marine hydroids and effects of environmental factors: A review: P.S.Z.N.I: Marine Ecology, v. 5, p. 93-118.

BransteTter, S., AND McEACHREN, J.D., 1986, A first record of Odontaspis noronhai (Lamniformes: Odontaspididae) for the western North Atlantic, with notes on two uncommon sharks from the Gulf of Mexico: Northeast Gulf Science, v. 8, p. 153-160.

CaIRNs, S.D., 1979, The deep-water Scleractinia of the Caribbean Sea and adjacent waters: Studies of the Fauna of Curacao and other Caribbean Islands, v. 57 , p. 1-341.

CAIRNS, S.D., 1986, A revision of the northwestern Atlantic Stylasteridae (Coelenterata: Hydrozoa): Smithsonian Contributions to Zoology, no. 418, p. 1-131.

CaIRNS, S.D., AND STANLEY, G.D., JR., 1982, Ahermatypic coral banks: Living and fossil counterparts: Proceedings of the Fourth International Coral Reef Symposium, Manila, v. 1, p. 611-618.

Clark, A. M., 1977, Notes on deep-water Atlantic Crinoidea: Bulletin of the British Museum (Natural History), Zoology, v. 31, p. 159186.

Conan, G., Roux, M., AND Sibuet, M., 1981, A photographic survey of a population of the stalked crinoid Diplocrinus (Annacrinus) wyvillethomsoni (Echinodermata) from the bathyal slope of the Bay of Biscay: Deep-Sea Research, v. 28A, p. 444-453.

DüING, W., AND JoHnson, D., 1972, Southward flow under the Florida Current: Science, v. 173, p. 428-430.

Genin, A., Boenlert, G.W., AND Lonsdale, P., 1984, Initial studies in seamount ecology: EOS, v. 65, p. 969.

Genin, A., Dayton, P.K., Lonsdale, P.F., And Spiess, F.N., 1986, Corals on seamount peaks provide evidence of current acceleration over deep-sea topography: Nature, v. 322 , p. 59-61.

GRIFFIN, S., AND DRUFFEL, E.R.M., 1989, Sources of carbon to deepsea corals: Radiocarbon, v. 31 , p. $533-542$.

GRIGG, R.W., 1974, Distribution and abundance of precious coral in Hawaii, in CAMERon, A.M., CAMPBEll, B.M., CRIBb, A.R., EndEAN, R., Jell, J.S., Jones, O.A., MATher, P., and TAlbot, F.H., eds., Proceedings of the Second International Coral Reef Symposium, Brisbane, v. 2, p. 235-240.

GRIGG, R.W., 1984, Resource management of precious corals: a review and application to shallow-water reef-building corals: P.S.Z.N.I: Marine Ecology, v. 5, p. 57-74.

GRIGG, R. W., 1988, Recruitment limitation of a deep benthic hardbottom octocoral population in the Hawaiian Islands: Marine Ecology Progress Series, v. 45, p. 121-126.

GrigG, R.W., Malahoff, A., Chave, E.H., and Landahl, J., 1987, Seamount benthic ecology and potential environmental impact from manganese crust mining in Hawaii, in KeATING, B.H., FrYer, P., Batiza, R., and Boenlert, G.W., eds., Seamounts, islands and atolls, Geophysical Monographs (43): American Geophysical Union, Washington, D.C., p. 379-390.

Hecker, B., Blechschmidt, G., and Gibson, P., 1980, Epifaunal zo- nation and community structure in three Mid- and North Atlantic Canyons (Canyon Assessment Study): U.S. Department of Interior, Bureau of Land Management, (Contract \#BLM AA551-CT849), Washington, D.C., 139 p. + appendices.

HEEZEN, B.C., AND Hollister, C.D., 1971, The face of the deep: Oxford University Press, New York, $659 \mathrm{p}$.

KINZIE, R.A., III, 1973, The zonation of West Indian gorgonians: Bulletin of Marine Science, v. 23, p. 93-155.

LANG, J.C., 1972, Biological zonation at the base of a reef: American Scientist, v. 62 , p. $272-281$.

Leaman, K.D., MolinaRI, R.L., AND Vertes, P.S., 1987, Structure and variability of the Florida Current at $27^{\circ} \mathrm{N}$ : April 1982-July 1984: Journal of Physical Oceanography, v. 17, p. 565-583.

LEEs, A., AND MILLER, J., 1985, Facies variation in Waulsortian buildups, part 2; mid-Dinantian buildups from Europe and North America: Geological Journal, v. 20, p. 159-180.

MACURDA, D.B., JR., AND MEYER, D.L., 1974, Feeding posture of modern stalked crinoids: Nature (London), v. 247, p. 394-396.

MaCuRDA, D.B., JR., AND MEYeR, D.L., 1976, The identification and interpretation of stalked crinoids (Echinodermata) from deep water photographs: Bulletin of Marine Science, v. 26, p. 205-215.

MALlOY, R.J., AND HURLEY, R.J., 1970, Geomorphology and geologic structure: Straits of Florida: Geological Society of America Bulletin, v. 81, p. 1947-1972 + map.

MessinG, C.G., 1984, Brooding and paedomorphosis in the deep-water feather star Comatilia iridometriformis A.H. Clark: Marine Biology, v. 80 , p. 83-92.

Messing, C.G., 1985, Submersible observations of deep-water crinoid assemblages in the tropical western Atlantic Ocean, in KeEGAN, B.F., and O'ConNOR, B.D.F., eds., Proceedings of the Fifth International Echinoderm Conference, Galway: A.A. Balkema, Rotterdam, p. 185-193.

MEYER, D.L., 1973, Feeding behavior and ecology of shallow-water unstalked crinoids (Echinodermata) in the Caribbean Sea: Marine Biology, v. 22, p. 105-129.

Meyer, D.L., Messing, C.G., ANd Macurda, D.B., JR., 1978, Zoogeography of tropical western Atlantic Crinoidea (Echinodermata): Bulletin of Marine Science, v. 28, p. 412-441.

Mullins, H.T., and NeumanN, A.C., 1979, Deep carbonate bank margin structure and sedimentation in the northern Bahamas: Society of Economic Paleontologists and Mineralogists special publication no. 27 , p. $165-192$.

Mullins, H.T., Newton, C.R., Heath, K.C., and Van BuRen, H.M., 1981, Modern deep-water coral mounds north of Little Bahama Bank: Criteria for recognition of deep-water coral bioherms in the rock record: Journal of Sedimentary Petrology, v. 51, p. 999-1013.

NeumanN, A.C., Kofoed, J.W., and Keller, G., 1977, Lithoherms in the Straits of Florida: Geology, v. 5, p. 4-10.

Newton, C.R., Mullins, H.T., GaRDULSKI, A.F., Hine, A.C., and Dix, G.R., 1987, Coral mounds on the West Florida slope: Unanswered questions regarding the development of deep-water banks: PALAIOS, v. 2, p. 359-367.

Pilskaln, C.H., Neumann, A.C., And Bane, J.M., 1987, Periplatform carbonate flux in the northern Bahamas. Deep-Sea Research, v. 36, p. 1391-1406.

PratT, R.M., 1967, Photography of seamounts, in Hersey, J.B., ed., Deep-sea photography: Johns Hopkins Press, Baltimore, p. 145158.

RIEDL, R., 1971, Water movement: Animals, in KINNE, O., ed., Marine ecology, v. 1, pt. 2: Wiley-Interscience, New York, p. 1123-1156.

SEBENS, K.D., 1984. Water flow and coral colony size: Interhabitat comparisons of the octocoral Alcyonium siderium: Proceedings of the National Academy of Science, U.S.A., v. 81, p. 5473-5477.

Slowey, N.C., NeumanN, A.C., and Baldwin, K.C., 1989, Seismic expression of Quaternary climatic cycles in the periplatform carbonate ooze of the northern Bahamas: Geological Society of America Bulletin, v. 101, p. 1563-1573.

SMITH, K.L., JR., and HINGA, K.R., 1983, Sediment community respiration in the deep sea, in Rowe, G.L., ed., Deep-sea biology: Wiley-Interscience, New York, p. 331-370. 
Sokolova, M.N., 1959, On the distribution of deep-water bottom animals in relation to their feeding habits and the character of sedimentation: Deep-Sea Research, v. 6, p. 1-4.

SQuiRES, D.F., 1963, Modern tools probe deep water: Natural History, v. 72 , p. $22-29$.

SQUIRES, D.F., 1964, Fossil coral thickets in Wairapapa, New Zealand: Journal of Paleontology, v. 38, p. 904-915, plates 147-148.

$\rightarrow$ Stanley, G.D., JR., and Cairns, S.D., 1988, Constructional azooxanthellate coral communities: An overview with implications for the fossil record: PALAIOS, v. 3, p. 233-242.

Stetson T.R., Squires, D.F., and Pratt, R.M., 1962, Coral banks occurring in deep water on the Blake Plateau: American Museum Novitates, no. 2114 , p. 1-39.

Teichert, C., 1958, Cold and deep-water coral banks: Bulletin of the American Association of Petroleum Geologists, v. 42, p. 1064-1082.

WILBER, R.J., 1976, Petrology of submarine-lithified hardgrounds and lithoherms from the deep flank environment of Little Bahama Bank (northeastern Straits of Florida): Master's Thesis, Duke University, Durham, North Carolina, $241 \mathrm{p}$.

Wilson, J.L., 1975, Carbonate facies in geologic history: SpringerVerlag, Berlin, 409 p. +30 plates.

\section{APPENDIX}

\section{ECOLOGICAL NOTES ON SELECTED SPECIES}

\section{Porifera}

Phakellia sp. is typical of low-relief hardgrounds and often generates a sediment shadow (Figs. 7A, 8A). It is short-stalked and flabellate, with a more or less discoidal filtration surface usually concave upcurrent. Unidentified decapod shrimp were sometimes observed resting on the upcurrent surface in the concave area just above the stalk, one to a sponge. Maximum density is 1 sponge $2-3 \mathrm{~m}^{2}$.

A species of Pachastrellidae (Pachastrella sp.?) resembles a tall narrow band shell or first-baseman's glove, concave upcurrent. Although most common on low-relief hardgrounds (Fig. 7A), it occurs on all hard substrates, including mound crests.

Members of the genus Hyalonema occur on soft substrates in which they anchor via long stalks composed of siliceous fibers. Unexpectedly, we most often observed specimens on hardgrounds. Deep, sediment-filled hollows on pavements and lithoherms may permit these sponges to anchor normally. No specimens were collected, however, and we cannot yet determine if any somehow attach to a hard substrate. Genin (personal communication) has also observed Hyalonema sp. on apparently hard substrates on the Jasper Seamount.

\section{Alcyonaria}

Candidella imbricata (Figs. 7A, 8B) forms monoplanar dichotomously branching colonies. It is usually far less abundant than the widespread Plumarella pourtalesi, but it is numerically dominant locally on some low-relief hardgrounds between lithoherms.

Paragorgia johnsoni forms purplish or orange flabellate colonies to about a meter tall and is the tallest of regular encountered taxa on lithoherm flanks and low-relief hard- grounds. As with other locally occurring monoplanar taxa, it orients normal to current flow. Every colony observed hosts a single, large, red-striped asteroschematid ophiuroid entwined in its branches.

Corallium medea (Fig. 7A) lacks the skeletal pigments characteristic of its commercially important congeners. Flabellate sparsely-branched colonies reach about $25 \mathrm{~cm}$ high. It is chiefly restricted to low-relief bottoms subject to reduced current velocities and typically attaches to flat sediment-veneered pavements and isolated, often buried bits of rubble or echinoid tests on unconsolidated bottoms.

\section{Zoanthidea}

Gerardia sp. (Fig. 6A-C): Small specimens have a few long branches, a colony form unlike that of other commonly co-occurring cnidarians. If this species must initially overgrow another axis-secreting cnidarian before producing its own axis (as has been suggested to us), it must do so at an early growth stage. Branches of large colonies often host a variety of epibionts (e.g., other zoanthids, hydroids, scalpellid cirripedes, galatheoid anomurans, brisingid asteroids, and Lophelia prolifera) (Fig. 6C). We observed slender, knifelike fishes (perhaps Ophidiidae or Bythitidae) hovering on the downcurrent side of some large colonies. Maximum density along ridge crests approaches 1 colony $/ \mathrm{m}^{2}$. The same or a similar species is harvested as "gold coral" in the Hawaiian Islands (Grigg, 1984). Identification of this species as Gerardia sp. is tentative; C. Arneson (pers. comm.) informs us that the genus may be synonymized under Parazoanthus.

\section{Polychaeta}

Eunice sp. produces an erect, loosely helical, chitinous tube, always covered by a colonial zoanthid. Several lateral openings as well as a terminal aperture exist. Tubes on sediment are probably anchored to buried hard substrates; they are also found on exposed hardgrounds. Its distribution appears to be patchy. Two of us (A.C.N. and C.G.M.) observed the same or a similar species on steep lithified escarpments in Northwest Province Channel, Bahamas. The relationship between worm and zoanthid is unclear.

Irregular tubelike burrows ostensibly created by polychaetes have also been found in thick basal branches of Lophelia prolifera colonies.

\section{Crustacea}

At least two species belonging to the superfamily Galatheoidea are most commonly seen in the Zoanthid Zone. Small white ?Chirostylidae (Fig. 6C) cling to large Gerardia sp. colonies. Large solitary squat lobsters, Eumunida picta Smith, are likely territorial on relatively barren bottoms. They usually assume a defensive or threat posture with raised chelae when approached. 


\section{Gastropoda}

Perotrochus midas Bayer (Pleurotomariidae), a large slit shell belonging to one of the most primitive extant gastropod families, was known from fewer than ten specimens before this study. Though nowhere common, one to three specimens were seen on almost every dive, all on lowrelief hardgrounds.

\section{Crinoidea}

Feeding postures and orientation of most local species have been discussed by Macurda and Meyer $(1974,1976)$ and Messing (1984, 1985). Their observations are briefly expanded upon here. A question mark precedes Diplocrinus because the species maclearanus may more correctly be assigned to the genus Endoxocrinus.

Isocrinus blakei (Isocrinidae) (Fig. 7B) occurs most often on flat sediment-veneered pavements, but is also found on open sediment. Confamilial Diplocrinus wyvillethomsoni (Jeffreys) from the eastern Atlantic anchors by grasping a single pebble or edge of rock in its terminal whorl of cirri (Conan et al., 1981). Because I blakei has particularly small delicate cirri and the local biogenic sand is noncohesive, it is most likely that individuals on unconsolidated bottoms are actually attached to buried hard surfaces (pavements, rubble or shell).

Members of the genus Democrinus (Bathycrinidae) occur in unexpected abundance on lithoherm flanks. Bathycrinids anchor to sediment bottoms via terminal, rootlike stalk extensions. Although we observed typical attachments to surrounding bottoms (Fig. 7B), and pockets of sediment are widespread on lithoherms, several visual and photographic records strongly suggest attachment to hard substrates as well. Broadening and fusing of terminal rootlets into an irregular holdfast have been noted previously (Clark, 1977; Messing, pers. obs.). A few observations of Democrinus on unconsolidated substrates suggest that this crinoid may bend into very low velocity currents. Although crinoids and other suspension-feeders normally orient foodgathering sủrfaces downcurrent, shallow-water, rheophobic comatulids orient their arms and food-collecting ambulacra randomly under conditions of weak, multidirectional flow. Food-gathering surfaces may thus face upcurrent at very low velocities. $D$. rawsoni (Pourtalès) is the most commonly collected local species.

\section{Asteroidea}

A large unidentified brisingid with 14 arms arranged in a broad bowl, clings to large Gerardia sp. colonies, a posture similar to that of other brisingids and ostensibly for suspension-feeding. In every case we observed, however, the brisingid, oriented vertically on the downcurrent side of a main branch, had stripped away all of the polyps and tissue below it.

\section{Fishes}

Benthopelagic fishes were never abundant. A small macrourid was the most frequently encountered teleost but was found singly and in small numbers on each dive. We observed it over sediment, hardgrounds and lithoherm flanks, always within a few $\mathrm{cm}$ of the bottom. Solitary or possibly paired wreckfish [Polyprion americanus (Bloch \& Schneider)] up to $1.5 \mathrm{~m}$ long appear to be resident on most larger lithoherms. Other species observed include Chaunax ?pictus Lowe, Polymixia sp., Beryx decadactylus Cuvier and a slender knifelike fish (ophidiid or bythitid?), the latter associated with Gerardia sp. On dive 1335 , Alvin was circled and bumped by an approximately $3 \mathrm{~m}$ long odontaspidid shark tentatively identified from videotape by C.R. Robins as Odontaspis noronhai (Maul). This species was recently recorded from the western Atlantic for the first time (Branstetter and McEachren, 1986). The specimen we observed appeared to be a pregnant female. 